\title{
Politics of Feminist Resistance in Nuruddin Farah's From a Crooked Rib and Lola Shoneyin's The Secret Lives of Baba Segi's Wives
}

\author{
د / نادر مصطفى احمد حلمي \\ ( مدرس الرواية بقسم اللغه الانجليزية بكلية التربية جامعة دمنهور )
}

\begin{abstract}
African feminist voices of the mid twentieth century to the present have vigorously tackled the intricate issues of sexuality, wifehood, motherhood, reproduction, polygamy, female circumcision, male supremacy, women's solidarity, and women's economic independence. With these issues in mind and guided by the principles of African Feminism, the present study aims at scrutinizing Nuruddin Farah's From a Crooked Rib (1970) and Lola Shoneyin's The Secret Lives of Baba Segi's Wives (2010) to investigate the politics of feminist resistance to patriarchal oppression in Somalia and Nigeria respectively. Analyzing novels written in East and West Africa, in which Muslims comprise the majority of the population, the study sheds light on how African women resist oppression in the name of religion; African men, as the analysis of the two texts will reveal, often twist and manipulate the meanings of the sacred texts to justify the subjugation of women.
\end{abstract}




\title{
سياسة المقاومة النسوية في رواية "من ضلع أعوج" لنور الاين فرح ورواية "الحياة

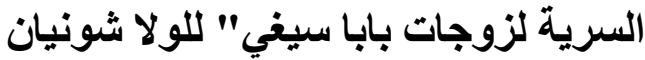

\begin{abstract}
ملخص

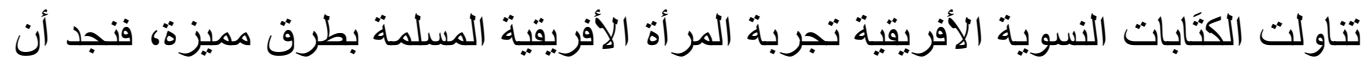
هذه الكتابات قد تتاولت العديد من القضايا الثائكة و التي تخص المرأة الأفريقية المسلمة مثل:

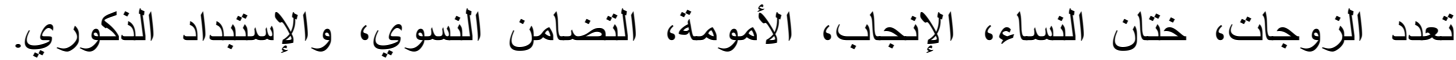

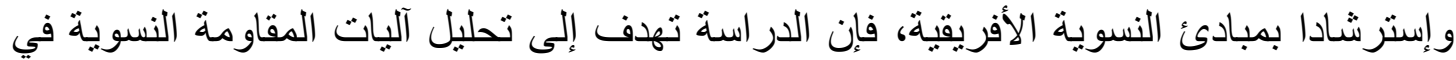

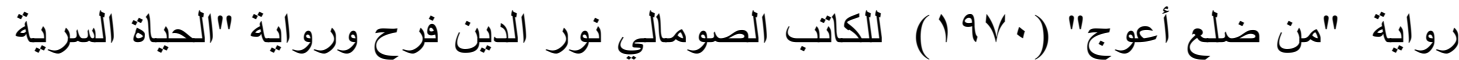

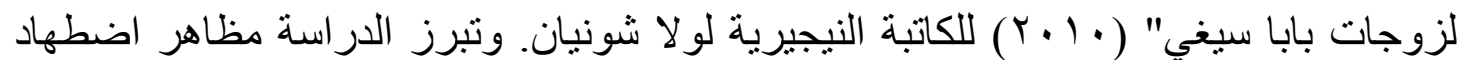

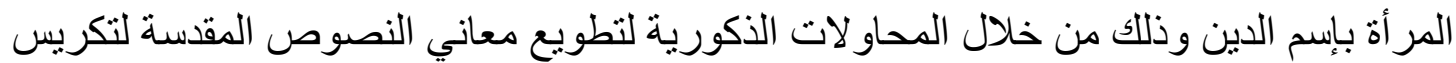

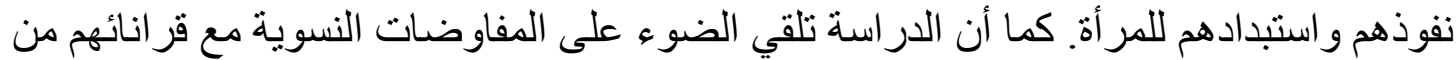
الذكور المستغلين لجسد المرأة من أجل الجنس والإنجاب من ناحية، و على المساعي الدؤوبة للمر أة الإفريقية لإقامة مجتمع عادل يستو عب الرجال و النساء من ناحية أخرى.
\end{abstract}

\section{Politics of Feminist Resistance in Nuruddin Farah's From a Crooked Rib and Lola Shoneyin's The Secret Lives of Baba Segi's Wives}

African feminist voices of the mid twentieth century to the present have vigorously tackled the intricate issues of sexuality, wifehood, motherhood, reproduction, polygamy, female circumcision, male supremacy, women's solidarity, and women's economic independence. With these issues in mind and guided by the principles of African Feminism, the present study aims at scrutinizing Nuruddin Farah's From a Crooked Rib (1970) and Lola Shoneyin's The Secret Lives of Baba Segi's Wives (2010) to investigate the politics of feminist resistance to patriarchal oppression in Somalia and Nigeria respectively. Analyzing novels written in East and West Africa, in which Muslims comprise the majority of the population, the study sheds light on how African women resist oppression in the name of religion; African men, as the analysis of the two texts will reveal, often twist and manipulate the meanings of the sacred texts to justify the subjugation of women. 
Both Nuruddin Farah and Lola Shoneyin are two remarkable African writers. Though a male writer, Farah is a mouthpiece of women's liberation and integration into the Somali society. For instance, when he submitted the script of his debut novel From a Crooked Rib to Heinemann's publishers, "they thought Farah was a woman writing under a male pseudonym; its feminist thrust was very strong" (Pucherova 33). Farah's writing extends over more than eleven novels and other fictive and non-fictive works. On the other hand, Lola Shoneyin is a Nigerian poet and novelist whose debut novel The Secret Lives of Baba Segi's Wives, translated into seven languages, made her a remarkable writer worldwide. In their novels, Farah and Shoneyin tell agonizing stories about polygamy, bride price, female circumcision, spousal violence, wifehood, motherhood, and sexual abuse. It is worth mentioning that though From a Crooked Rib was written in 1970 to portray the circumstances and practices which brought about subjugating Somali women, these circumstances and practices are quite similar to those which repress women in 2010's Nigeria as depicted in The Secret Lives of Baba Segi's Wives.

The politics of resistance in Farah's From a Crooked Rib and Shoneyin's The Secret Lives of Baba Segi's Wives refer to the strategies through which the female characters get into negotiations with their male counterparts in the hope of capturing the attention of the patriarchal society to their predicament. These feminist politics include utilizing the female body as a powerful entity to achieve considerable liberation, forming an all-female community to fight back male oppressors, pursuing education to teach others about feminist causes, and achieving economic independence to have individual autonomy.

The study is divided into three main sections. The first section is intended to provide a brief summary of the principles of African Feminism. The second section, entitled 'the Female Body as Enslaving', is concerned with the aspects of gender inequality and oppression women characters suffer from. The third section, entitled 'Politics of Resistance', is concerned with the strategies adopted by those women to resist and defeat such inequality and oppression. With their bodies as both 'enslaving' and 'empowering', African women get into negotiation with their male counterparts to find new spaces of exercising power and resistance. Accordingly, the writers in the study interrogate the patriarchal structures in their societies in which the female body is subordinated and exploited to maintain male dominance, while at the same time exhibits politics of resisting these oppressive structures. 


\section{African Feminism}

African women practiced feminism even before the term was coined. Adeleye-Fayemi argues

Africa has some of the oldest civilizations in the world, it has the oldest patriarchies, and therefore the oldest tradition of resistance to patriarchy. To believe otherwise is to falsely imply that for centuries African women have crossed their arms and accepted being battered and depersonalized by patriarchy $(88)$.

Tracing the origin of African Feminism, Gwendolyn Mikell contends that the emergence of African Feminism is noticeably heterosexual, and concerned with many cultural issues. The newly emerging African Feminism has been the upshot of women's responses to political leaders who have saved no effort to practice power and exploitation over women. Mikell registers how women merchants challenging the excessive prices set by the government were beaten and had their shops burnt down. Similarly, professional women who organized campaigns for better wages and working conditions were fired from their positions (12-14).

African Feminism is located within the harsh realities of marginalization, slavery and oppression which were brought about by colonialism, imperialism, and globalization (Alison and Young 101). The term was initially used to reconstruct the presence of African women in history and to reconstruct a framework to criticize white hegemonic feminism (Ibid 102). Filomina Chioma Steady defines African Feminism as "a movement which combines racial, sexual, class and cultural dimensions of oppression to produce a more inclusive brand of feminism through which African women are viewed first and foremost as human rather than sexual beings" (5). Generally, there are seven main points through which one can develop a better understanding of African Feminism: colonialism, patriarchy, sexuality, tradition, racism, economic independence, and women's solidarity.

\subsection{Colonialism}

As mentioned above, African Feminism was initially an antagonistic response against Western Feminism. Femi Ojo-Ade, for example, dismissed feminism as a western "invention" that has nothing to do with true African women. He even suggested that feminism is only an attempt to convert women to be men (158-79). Chinweizu, the author of The West and the Rest of Us, dismissed feminism on the same ground. 
The Ghanaian writer, Florence Dolphyne, also expresses her concern with the term:

I never considered and still do not consider myself a 'feminist', for the term evokes for me the image of an aggressive woman who, in the same breath, speaks of a woman's right to education and professional training, her right to equal pay for work of equal value, her right to vote and to be voted for in elections at all levels, etc. as well as a woman's right to practice prostitution and lesbianism. (xiii)

Such hostility towards Western Feminism gave rise to other non-white movements that have been striving to find a place for women in the patriarchal societies. Though the pioneers of these movements initially did not call themselves feminists, one can easily discern the impulses of feminism in such movements. One of these non-white feminist movements is African Feminism.

Western Feminism has been mainly concerned with the issues of white middle-class women. In the 1980s, women intellectuals belonging to the minority cultures in the West along with women in Africa, Asia, the Middle East, and Latin America pointed out the inadequacy of Western Feminism (McLeod 55). African Feminism is, accordingly, seen as part of the third-wave feminism, which highlights, among other things, the failure of Western Feminism to address the role of racism, colonialism and imperialism in the subjugation of African women (Ibid 56). Therefore, African feminist writers do not see first world feminists as "sisters" as McLeod rejects the assumption of "universal sisterhood and the so called first-world feminists' right to speak for the so-called third world women" (58).

\subsection{Patriarchy}

Emphasizing issues of colonialism, racial discrimination and imperialism does not mean that Western Feminism and African Feminism have nothing in common. Both waves of feminism differ in priorities, but when the matter of patriarchy shows up, they stand together against their enemy to defeat it. According to Tyson, all feminists, including African feminists, share a belief that patriarchal ideology works to keep women and men in traditional gender roles and hence to maintain male dominance in all aspects of life (91-92). 
Although Western Feminism and African Feminism share a common view of the necessity of fighting patriarchy, their mechanisms for such fighting are extremely different. While Western radical feminists exhibit a negative view of men and a radical desire to discard men from their realm, Africa feminists do not take an antagonist attitude towards African men. African feminists believe that African men and women could have mutually transformative and progressive relationships in a complementary fashion that can ultimately achieve an egalitarian sphere. Men are, therefore, not discarded from African feminists' pursuit of equality, for African women cannot imagine a life without their menfolk. For African women, the male is not 'the other'. Each gender constitutes the "critical half that makes the human whole. Neither sex is totally complete in itself. Each needs a complement, despite the possession of unique features of its own" (Steady 8). Traditionally, women and men in many African societies occupied "separate, non-hierarchically harmonizing spheres which both incorporated the public and private and were internally hierarchically ordered" (Sudarkasa 94). Women do not aspire to exchange roles with men as long as they are respected by their menfolk.

By appealing to men's commonality and solidarity, African feminists seek to enlighten men about the discrimination which women have experienced due to the patriarchal structures of their societies as well as the oppressive gender practices of individual men. Accordingly, these feminist endeavors are mainly based on men's understandability of women's predicament. However, if it happens that men disappoint this trust and show resistance to women's endeavors for emancipation and integration, those men will be regarded enemies, and thus a war should be declared against them. Ogundipe- Leslie explains:

No, men are not the enemy. The enemy is the total societal structure which is a jumble of neocolonial and feudalistic, even slave-holding structures and social attitudes ... As women's liberation is but an aspect of the need to liberate the total society from dehumanization and the loss of fundamental human rights, it is the social system which must change. But men become enemies when they seek to retard, even block, these necessary historical changes for selfish interests in power, when they claim 'culture and heritage' as if human societies are not constructed by human beings, when they plead and laugh about the 'natural and enduring inferiority of women', when they argue that 
change is impossible because history is static, which it is not (25).

\subsection{Sexuality}

Controlling and enslaving the female body and converting it to a commodity used for sexual and reproduction purposes is, in fact, a central preoccupation for African feminists. Contemporary African feminist writers-Farah and Shoneyin are two examples - are preoccupied with the female body as a violated entity. They see the female body not as a symbol of something else, but rather as a home to the individual 'self' (Eze 13). Farah, Shoneyin and other writers express their sympathy for the commodification of the female body and the physical and psychological pains resulting from possessing and controlling it. In the course of their emancipation process, women characters in the novels under study, utilizing their bodies, exhibit a capability of resisting gender oppression.

\subsection{Tradition}

African traditions, particularly tribal ones, are criticized by African feminists for the oppressive gender distinctions they establish between men and women. Such distinctions privilege men on the one hand, while disadvantage women on the other hand. African women have been muted for too long about the traumatic effects of African tradition such as the offensive and dehumanizing institution of patriarchal polygamy, forced marriage, bride price, female circumcision, and misogynist inheritance laws. However, African feminist thought is not willing to abandon all African tradition, for tradition also "harbors a valuable cultural memory and a rich legacy of knowledge and spirituality" (Ogundipe-Leslie 27). Rather, African feminists seek to adapt such tradition to feminist goals. They, for instance, do not reject the bride price, but it is up to the woman to decide what and how this price is paid (Ibid 28).

Within the framework of African Feminism, wifehood and motherhood are highly estimated by the African culture. The problem, however, lies in the fact that the excessive practice of this culturally accepted norm will eventually lead women to be restricted to the prescribed roles of being a wife and/or a mother; there will be no more alternatives. This, in turn, gave rise to more liberating voices in African feminist theory in which women should not be evaluated only by their sexual, reproductive and nurturing capabilities. Susan Moller Okin contends that "women should not be disadvantaged by their sex, that they 
should be recognized as having human dignity equally with men, and the opportunity to live as fulfilling and as freely chosen lives as men can" (13). The novels under study recognize that at different points in women's lives, alternative identities rather than being wives or mothers might be more advantageous. Yet, this is not easy for women to attain where patriarchal societies insist on the so-called fundamental goals of women's existence: sex and reproduction.

\subsection{Racism}

African feminist thought does not only examine the male-female dichotomy, for that will ignore other factors that affect African women's lives. One of these factors is racial discrimination and the politics resulting from them. African feminist writing aims to unmask the practices that made Africans dependent on their colonizers, to disclose the burden of imperialism that spans through centuries, and to give a new language that enables both men and women to transcend the repercussions of racial discriminations (Hogan34). However, Farah and Shoneyin do not tackle racial issues in their novels for Somalia and Nigeria do not have long history with racism. Susan Arndt explains:

Southern African feminist writers frequently direct their criticism of gender relationships to the issue of "race", while many feminist writers from West or East Africa do not write about "race". This has much to do with the fact that in Southern Africa, Blacks suffer daily and severely from racist discrimination and the issue of "race" is at the core of social debates and interactions, while "racial discrimination" is not a main issue inside postindependence countries of most Western or Eastern Africa (29).

\subsection{Economic Independence}

African feminist writing emphasizes the importance of achieving economic independence for women so that they can achieve self-reliance and individual autonomy. In many African countries, women cannot get a credit card, employment contract or visa without their husbands' consent. African women in almost all communities have always worked. They have worked within and outside their homes. They have made significant contributions to the economies of their communities through the provision of cheap labor and endless production (ibid 64). African Feminism is, therefore, concerned with women's equality in the administration of justice as well as in monetary issues. 


\subsection{Women's Solidarity}

In African Gender Studies: A Reader, Oyeronke Oyewumi suggests ways in which women can attain power to strike a gender balance. Oyewumi suggests the formulation of "different groups of marginalized women [that] can create new spaces and social locations for themselves within the dominant culture [...]. By creating these new spaces and locations, women take the margins to the centre and vice versa" (273). African feminist writers show in their texts how women's immense power for positive transformation both for themselves and for their whole society can be attained when women are united against their oppressors. An apt example is found in Shoneyin's The Secret Lives of Baba Segi's Wives where the female bonding in the Baba Segi's household manifests women's solidarity and commonality. This bonding, as will be discussed later, proves that polygamy as a cultural system can be manipulated and defeated when co-wives are united.

\section{The Female Body as 'Enslaving'}

Farah and Shoneyin maintain that the patriarchal system defines the female body using physical differences and by doing so guarantees the subjugation of women. An important concern of Feminism in general and African Feminism in particular is the treatment of woman as a commodity sold by and for men. The tropes of woman as a 'commodity' and as 'cattle' are manifested in Farah's From a Crooked Rib which tells a story very similar to Shoneyin's The Secret Lives of Baba Segi's Wives. Ebla, the protagonist of From a Crooked Rib, gives utterance to this notion: the commodification of the woman's body and psyche:

From experience she knew that girls were materials, just like objects, or items on the shelf of a shop. They were sold and bought as shepherds sold their goats at market places, or shop-owners sold the goods to their customers.... What makes women so inferior to men?...For sure this world is a man's it is his dominion. It is his and is going to be his as long as women are sold and bought like camels (Farah 84).

A neighboring widow also stresses the same point of commodifying women when she tells Ebla, "But that is what we women are- just like cattle, properties of someone or other, either your parents or your husband [...] What is the difference between a cow and yourself now?" (Farah 80)

In From a Crooked Rib, Farah presents Ebla as an orphan girl and a villager. Though illiterate, Ebla will not accept an old man's proposal 
already approved by her grandfather in exchange for camels. However, when escaping such hostile environment, she finds herself victimized by her Uncle Gheddi who marries her off to a sick person for a thousand shillings to enable Gheddi pay off the police's fine for smuggling. Since "girls are like materials, just like objects or items on the shelf of a shop" (Farah 84), Ebla makes up her mind to sell herself to Awill, without a bride price: "all I need is the Sheikh's fees and two witnesses" (Farah 85), she says to validate her relationship with Awill. She elopes with Awill to Mogadiscio, where Awill rapes her before marriage.

Since a woman is seen as a commodity, it follows that her body belongs to her male owner(s). Ebla's body is seen to be the property of her family: her grandfather and her little brother. Ebla's predicament is represented by her family's unrelenting attempts to get advantage of her 'body'. Ebla's body becomes the thing that her grandfather is "exchanging...for camels" (Farah 9). Ebla's body is, therefore, a product that can be sold, bought, re-sold, and re-bought. The Somali family in the novel does not see the female body as a free entity; it is rather seen as part of the family's possession that can be traded for goods and money. As explained in the theoretical part of the study, forced marriage is a significant preoccupation for African Feminism. Accordingly, Farah raises the issue in his narrative to interrogate such practice whether it is performed on traditional or religious basis. ${ }^{1}$

The commodification of Ebla is extended to include other owners in her endeavor to escape from the marriage arranged by her grandfather to the old man, Giumaleh. As a matter of fact, Ebla's arranged marriage to Giumaleh takes place after "two of his sons had alternately courted her" (Farah 9). Her body is eventually seen by both her family and the Giumaleh's family as an asset that needs to be utilized. This explains Ebla's family's rejection of Giumaleh's sons' proposals; her grandfather needs to make sure that he benefits from it the most. Giumaleh's sons did not pay the satisfactory 'price' for Ebla's body; but Giumaleh paid camels for her, one of the most valuable bride prices in the Somali countryside.

Ebla, consequently, comes to a conclusion, "I know I am just as much as a beast as they (cows) are" (Farah 36). She equates her body with the bodies of the cows, for she feels a kind of fellowship and sympathy with them. The commodification of Ebla's body is the ultimate result of "creating desires, attaching individuals to specific identities, and establishing norms against which individuals and their behaviors and

\footnotetext{
${ }^{1}$ Islam is against forced marriage according to the Hadith narrated by Abdullah Ibn Abbas that marriage is invalid without the woman's consent. Hence, forced marriage is attributed to tradition.
} 
bodies are judged and against which they police themselves" (Sawicki 68). According to Islamic Faith, woman is created from the body of man (from a crooked rib). Herein lies the symbolic significance of the title of the novel; the body of woman is seen by Farah as a continuation of the body of the man. Thus, to protect the honor of the body of the woman is equal to protect the honor of the man and his body. Ebla's body is hallowed not because of Ebla herself, but rather because of what her body symbolizes.

While in the countryside her grandfather gave her hand to a man without her consent, in the town she experiences the same trauma. Uncle Gheddi is indebted to the colonial authority and, therefore, is forced to marry off Ebla to get money that helps him pay off his debts; he sells a cow for the same reason. This means that colonialism worsens Ebla's condition. As Patrick Colm Hogan writes, "at least in this way, colonialism does not improve but worsen[s] the situation of women" (174). Accordingly, one can notice an important aspect of African Feminism which stresses the devastating impact of colonialism on African women. Colonial power which is an important aspect of African Feminism is highlighted in the novel as an oppressive force of subjugating Ebla.

The trope of 'woman as a commodity' is also manifested in The Secret Lives of Baba Segi's Wives which narrates the story of a polygamous family and its dynamics. The novel tells the story of the polygamous husband Baba Segi, who has four wives: Iya Segi, Iya Tope, Iya Femi and Bolanle. Set in a modern town, Ibadan, the novel reveals how literate and illiterate women are enforced by circumstances to marry into polygamous practices and hence seen as commodities sold by and for men.

The women in the novel live within the confines of a polygamous family. The 'more wives' means 'more hands' to cultivate the fields and to insure the nourishment of the house. In such a situation, older wives often welcome younger wives to participate in their domestic and agricultural tasks. Many women recognize the benefit of having additional help in running their households:

African traditional civilization was an agricultural one. Therefore the role of women is characterized by motherhood, hospitality and life with man. The African woman used to be a strong economic asset and neither polygamy nor the bride price must be regarded as degrading factors. Polygamy is linked 
with the weaning of children and only the passage to cash economy made the bride price what it is at present (Pfaff 29).

Over the ages, polygamy has remained a debatable topic for African women. The topic receives conflicting attitudes in African cultural circles; from complete acceptance to total disapproval. Obioma Nnaemeka suggests that totalizing disapproval about polygamy is wrong. Nnaemeka refers to the point that most feminists are blind to the fact that "African women actually choose to have co-wives and some choose to be circumcised. African women who are in polygamous marriages are not morons or powerless, exploited, downtrodden victims (168). Commentators such as Aina and Ogundipe-Leslie represent the other side of the debate. Ogundipe-Leslie, for example, identifies polygamy as a form of oppression which turns African women into chattels (33). 'Many wives' also means 'many descendants'- essential to strengthen a man's position in his community. This proved his virility; and whilst sons continued and expanded the clan, "marriage of daughters provided cattle and created relationships with other lineage groups" (Silberschmidt 241). In line with African Feminism, the novels under study have adopted a hostile attitude towards polygamy, presenting it as a "continual source of female suffering and oppression" (Ndabayakhe and Addison 90).

Believing that he abides by the Islamic Law, Baba Segi holds four wives simultaneously, "I'm enjoying my right as a Muslim" (Shoneyin 84). Baba Segi rests his polygamous stance on the third verse in Surat An-Nisaa in the Holy Quran which sanctions the man's right to marry four women at the same time. However, the same verse sets an important (practically impossible) condition to have this right, "but if you (men) fear that you shall not be able deal justly (with those wives), then only one ... That is nearer to prevent you from doing injustice" (al-Hilali and Muhsin Khan, 105). Hence, the manipulation of the sacred texts by either twisting their meanings or skipping some of the completing meanings result in women's oppression.

Baba Segi's four wives: Iya Segi, Iya Tope, Iya Femi and Bolanle ${ }^{2}$ are also portrayed as commodities. Their existence in Baba Segi's household is restricted to two main areas: sex and reproduction. Accordingly, achieving such goals means 'survival', while failing to meet them leads females to be stigmatized as "barren".

\footnotetext{
2. "Baba" and "lya" are titles given to husbands and wives respectively, and which are followed by their eldest kid's name.
} 
Iya Segi is the first of Baba Segi's four wives. Influenced by her mother's resentment towards men, Iya Segi takes a similar attitude. Iya Segi's mother articulates feminist politics of resistance against patriarchal power by advising her daughter to reject the institution of marriage, "Men are nothing. They are fools...... Only a foolish woman leans heavily on a man's promises" (Shoneyin 97). This convinces Iya Segi that her only means of protecting herself from being victimized by the patriarchal marriage is through her economic independence. By making and selling fufu (one of the traditional foods among the Nigerian Yoruba), Iya Segi gradually becomes a money worshiper. Paradoxically enough, it is Iya Segi's mother who eventually forces her daughter to accept the tradition of their community, "It is every woman's life purpose to bear children. Do you want to become a ghost in the world of the living? That is not how I want to leave you in this world. [...] The world has no patience for spinsters. It spits them out" (Shoneyin 111-13). Iya Segi's mother is in need to guarantee the continuity of her daughter's lineage. As a result, she collects the money which Iya Segi has accumulated over the years and gives it to Baba Segi to accept to marry her daughter. Commodifying women, this time, is done by women themselves. Her argument about the prescribed roles of African women confirms Ngcobo's scrutiny that in many African societies "every woman is encouraged to marry and get children in order to express her womanhood to the full. The basis of marriage among Africans implies the transfer of a woman's fertility to the husband's family group" (141). A woman without a child in such societies, as the ones in The Secret Lives of Baba Segi's Wives, is seen as incomplete and becomes what John Mbiti defines as the "dead end of human life, not only on genealogical level but also for herself" (144).

Iya Tope's father was a hired farmer in Baba Segi's farm. When crops were damaged due to severe drought, Iya Tope's father asked Baba Segi to accept his daughter as a bride as a kind of compensation. To promote his "commodity", Iya Tope's father praises her in the presence of Iya Segi as being 'strong as three donkeys'. Without Iya Tope's consent, these two men have reached a 'deal' that leads to the girl being possessed by her husband. When Iya Tope fails at the beginning to conceive, Baba Segi threatens her "if your father has sold me a rotten fruit, it will be returned to him" (Shoneyin 93). He, therefore, underlines Iya Tope's utilitarian importance.

Shoneyin criticizes the patriarchal system that defines a woman's body in terms of her physical values. As Ebla thinks of herself as one who has been reduced to the level of an object, Iya Tope grasps the same recognition when she thinks that she is just like "tubers of cassava in the 
basket. May be something even less, something strange - a tuber with eyes, a nose, arms and two legs" (Shoneyin 82). In this context, the female is not only denied the right to speak her mind in public, but is also used as a symbol for survival of family members; for it is Iya Tope's womanhood that rescues the family from famine. Having no other alternatives, Iya Tope is satisfied with her fate, recognizing Baba Segi, "the master", as "her only salvation" (Shoneyin 94).

Iya Femi is also objectified by her male relatives and later by her husband Baba Segi. Contrary to Islamic jurisdiction which gives women the right to inherit their fathers, Iya Femi was deprived by her uncle from inheriting her father's house. In East Africa, the status of African woman is similar. Ebla, reflects on how she was deprived from her inheritance: "as many as twenty or thirty camels are allotted to each son. The women, however, have to wait until their fates give them a new status in life: the status of marriage" (Farah 21). Ebla points out that, unlike men, women in traditional Somali society are deprived of economic independence. They are never allowed to own property or anything else; they are owned by their male counterparts and the only hope for them to gain some respect is to marry a man and to become his other 'half'. Grasping the same recognition that her respect will be accomplished only through the institution of marriage, Iya Femi begs Taju, Baba Segi's driver, to help her find a husband, "Then make him (Baba Segi) marry me. Convince him and put me in your debt forever. I have no relatives so there is no one for him to pay homage to' (Shoneyin 144). Marriage for Iya Femi is, therefore, seen as her salvation from being homeless and penniless, for she is denied the access to have economic independence. The question that the narrative raises is 'would Iya Femi, and other women as well, seek marriage if she could sustain herself economically'. We understand her endeavor to get married to a wealthy man as an effort to survive in a culture that has a limited space for poor women.

The last commodity (wife) to be discussed in the novel is Bolanle. While the first three wives of Baba Segi mainly decide to marry him to escape from poor living conditions in their homes, Bolanle decides to marry Baba Segi to escape her mother's ill treatment. When getting married to Baba Segi, Bolanle is claimed to be barren; that is why she is not entitled "Iya". At the outset of the novel, a friend asks Baba Segi to "drag her to a medicine man if she doesn't follow. You are the husband and she is a mere wife ... If you drag her by the hair, she'll follow you anywhere, I swear it!" (Shoneyin 4). The quote sheds light on the trope of 'women as cattle' as well as women's destiny when not performing their job: reproduction. Baba Segi tells the doctor that they have been married 
for about three years, but she is still barren. Bolanle is to take the responsibility of her physical defect; though later we understand that it is Baba Segi who is impotent. Shoneyin is, therefore, casting doubt on the assumption that polygamous marriages are willfully accepted by women. Shoneyin shows how much pain each wife in Baba Segi's household endures on the arrival of a new co-wife. Bolanle is, however, the unluckiest of them as they (Iya Segi, Iya Tope, and Iya Femi) plot against her out of jealousy. Iya Tope narrates:

Iya Segi told us she had changed her plan, that it was no longer enough to wait until Bolanle's barrenness made Baba Segi chase her out. Iya Segi said we had to join hands and force her out. 'Don't you see her high brow and unconcerned eyes? She thinks we are beneath her. She wants our husband to cast us aside as the illiterate ones,' she said. (Shoneyin 52)

This 'female' plotting against women stands, therefore, against an important principle of African Feminism: women's solidarity. This justifies the proposition set at the beginning of the present study that contemporary African Feminist writers have developed a more radical stance against polygamous marriages, unlike those who defend the practice. Shoneyin was frank about her views on polygamy as an oppressive practice that sets women against each other. In an interview with Nana Fredua-Agyeman, she claims that

As an institution, polygamy brings out the worst in the women involved. There isn't one woman alive who wouldn't rather have their husband to themselves, who wouldn't want all the children in the household to have come from them. What this tells me is that most women who are living in these circumstances just grin and bear it. The senior wives often don't have a choice and for their own survival, they learn to bottle up their misery and the sense of betrayal they feel. Most times, they take it out on the new wife who, justifiably, is viewed as a usurper. The newer wives know what they are in for so they come in itching and spoiling for a scrap. Most of the fighting is done behind the husband's back. In his insensitivity and ignorance, he boasts to his friends that his wives get on swimmingly (Fredua-Agyeman, blogspot.co.za) 
Shoneyin refers to the inevitable destiny of polygamy and women's powerlessness to resist it. This point is already accentuated by Ebla in From a Crooked Rib:

I am a woman and for a woman there are many limitations. For one thing, Awill could marry another woman and bring her home, and I would not be able to say another word .... The concessions given to men are far too great. (Farah 152-154)

As the female body is claimed to be man's property, it follows that this body should be controlled. One of the male tactics of controlling woman's body is through controlling her sexual desire. Surgical procedures are used in some cases to stop women from enjoying intercourse and therefore guarantee her chastity; the procedure, however, results in wives being unable to have normal and healthy relationships with their husbands. This means that patriarchal oppression is not restricted to the psychological domain of the woman, but it exceeds to include agonizing bodily procedures such as female circumcision, a practice that is widespread in Somalia and Nigeria. The bitter memory of circumcision is present in Ebla's mind as she rehearses every detail of the brutal operation:

She recalled everything. They had sliced out her clitoris and stitched the lips together, thus blocking the passageway, but also leaving a small inlet for urinating through. They had tied her legs together, and she had lain flat on the ground without any mattress..... They had beaten drums when the girls cried, so that the beating of the drums would drown the crying. If a girl cried too much, they tucked a piece of cloth into her mouth (Farah 149-150).

The function of female circumcision is, thus, to uphold male control over women's sexuality and reproduction, and even more to perpetuate men's power over women's desires and individuality. Circumcision in the eye of a child is a muted pain full of brutality. Therefore, the sacred tradition that witnesses a girl's transition to womanhood reveals the deep-rooted inequality between men and women.

In From a Crooked Rib and The Secret Lives of Baba Segi's Wives, men are portrayed as egocentric and as excessively driven by their sexual impulses regardless of the physical and emotional damage these impulses could cause. Baba Segi's notions of masculinity stem from egoistic notions about male virility and sexual performance. Iya Segi declares this 
point, "[w]omen are my husband's weakness. He cannot resist them, especially when they are low and downcast like puppies prematurely snatched from their mothers' breasts" (Shoneyin 103). Women, for Baba Segi, are sexual slaves. Vulnerability in women appeals to his male ego as it gives him the freedom to exercise his masculinity.

The violation of the female body and sexuality has been a main concern in feminist studies. Ouzgane and Morrell maintain that sex is authorized to "reaffirm aggressive heterosexual masculinity and to assert control over women" (22), especially in contexts where "the ruling form of masculinity supports the idea of females being subjected to males" (23). Jennifer Oriel believes that while "sexual rights advocates recommend that sexual pleasure should be recognized as a human right...the construction of sexuality as gender-neutral in sexual rights literature conceals how men's demand for sexual pleasure often reinforces the subordination of women's sexual enjoyment" (392). These discussions are illustrated through Baba Segi's sexual relations with his wives. Although he exhibits egoistic attitude about his powerful sexual performance, he denies his wives the right to have the same sexual pleasure he enjoys. Baba Segi's aggressive sexual behavior has also manifested itself when Bolanle fails to get pregnant. Lest he is accused of being sexually deficient, Baba Segi is rather raping Bolanle as revealed in the scene below:

It must have been my vulnerability that aroused him because he returned at midnight to hammer me like never before. ..... It was as if he wanted to make it clear, with every thrust, that he didn't make light of his husbandly duties. [...]. If there was ever a moment when the memory of being raped became fresh in my mind, that was it (Shoneyin 44)

Bolanle, who was raped at the age of fifteen, is thus presented as a victim of repetitive rape: from a friend and then from a husband. The occurrence of rape in patriarchal societies as evidenced by the two texts marks such violations on women's bodies and integrity.

In like manner, in From a Crooked Rib Awill's major reason for marriage is his wish to have a permanent sexual partner to stop spending much money on prostitutes. When Awill marries Ebla, he believes he has the right to enjoy having sex with Ebla's body even if Ebla does not welcome it. Ebla fears that he may not admit the union if he invades her virginity before the official marriage ceremony. In addition, Ebla heard lots of women talk about the pain a virgin has to endure when she has her 
first sexual intercourse. However, Awill physically beats her into compliance, "She [Ebla] had bled and he [Awill] rejoiced seeing her blood, as his manhood depended upon breaking his chastity" (Farah 150). By doing so, he not only violates her dignity and pride, but he also exposes her to physical damage and suffering due to the circumcision that she was subjected to in her childhood. She withstands this violence in lip-biting silence. Raping and sexual abuse, two concerns of African Feminism, are, therefore, highlighted in the two novels.

\section{Politics of Resistance}

As a reaction to men's endeavors to possess and control the female body, the women characters in the novels under study adopt certain politics of resisting and defeating such male endeavors. Hence, negotiating an agreement with men entails exploiting the powerful means left to them in their husbands' confinement; one of them is, of course, their bodies. These women have developed consciousness that their bodies can be utilized as a source of empowerment.

Having realized the value of her body, Ebla states, "This is my treasure, my only treasure, my bank, my money, my existence" (Farah 160). Now Ebla sees her body as her own asset, not her family's nor her husband's. Consequently, Ebla's body will empower rather than enslave her. Ebla's response to fight back her oppressors is challenging and appalling. She is no longer submissive, rather she will subvert the trope of women as 'cattle'. By deciding first to escape the arranged marriage, Ebla intends to "break the ropes society had wrapped around her and to be free and be herself", to "go away from the duty of women" (Farah 12-13). In another occasion, she stresses the same rejectionist attitude against forced marriage, "I don't like this sort of marriage... I don't want to be sold like cattle...we are human beings" (emphasis added, Farah 79-80).

Ebla thinks in a way that is totally different from her peers; she determinedly denies the passive role imposed by her society on women. Moreover, she disapproves of the idea of male superiority and sees herself as an equal being to men. Though illiterate, Ebla nurtures these emancipating ideals as she is growing in a male-centered society where she is denied the access to educational opportunities. Such ideals are then 
fostered when she escapes from her first arranged marriage, "Ebla's escape is a self-emancipation which allows her to test her self-reliance and allows her to establish herself as her own self-creator" (Okonkwo $68)$.

According to African Feminism, women are supposed to be united to face their oppressors. Such feminist unity is meant to sustain women in their endeavor to liberate themselves from male control. However, as explained before, such unity, unlike western feminist ones, is not intended to enforce a separatist attitude between men and women in the African societies.

Ebla's journey towards liberation makes her get into contact with two women in Mogadishu: a nameless widow and Asha. The widow is presented as a moderate and free going lady who rejects the conventional role of women and hence leads a life of her own; a life that is characterized by economic independence. Through the widow, Ebla comes full circle about the realities of colonial men and other staff necessary for urban women. Asha takes part in Ebla's transformation from being a docile wife to a radical woman able to reconstruct her own reality. Asha is also the first person who is even considered her equal. She makes Ebla "aware of what she was" (Farah 121). The awareness of the self is vital for female liberation and empowerment. Gradually, Ebla and Asha get into what is seen as a feminist bond which interrogates the submissive status imposed upon them in the name of religion and tradition. According to Okonkwo, in the character of Asha "Farah creates a strong feminine independence in order to portray the potential of individual achievement in a world dominated by men" (70).

Asha's character can be seen within two main domains: female biology and female psychology. Biologically, Asha holds the belief that a woman is in need to use her body to protect herself from the ravages of life like poverty. Psychologically, she embraces the notion that a woman is a clever negotiator who can defeat man's arrogance with female tactics. Thus, Asha instills in Ebla's mind the idea that she is equivalent to man on the one hand, and that she has to fight back her oppressor, using her body, on the other hand.

Having recognized that Awill is betraying Ebla with an Italian girl, Asha tells her that since a man has the privilege to have more than one wife then the woman has the same privilege to have 'more than one husband'. Asha strikes while the iron is hot and offers Ebla a person who is interested in her. Shockingly, Ebla expresses her readiness to "marry" 
him and even implies that she 'is already married to two men'- to the man whom grandfather gave her hand and to her current husband Awill, "Tell him that I am willing to marry him secretly," and "I love life, and I love to be a wife. I don't care whose" (Farah 112-13). Ebla's decision to secretly have a "second husband" while yet married to another one is a radical response to the polygamous marriage system in her society.

Getting married secretly in Somalia, like that in Nigeria, is a privilege that gives the man the right of having more than one wife without informing his first wife. Ebla, appreciating the significance of her body to attack and disrupt male dominance, benefits from the same practice and turns the whole idea of secret marriage upside down; she becomes polygamist herself. In doing so, she expresses her will to "to reform him (Awill), to teach him, to break his pride, to turn him into a human being'" (Farah 85).

The conversation between Ebla and her "second husband" Tiffo is a manifestation of her free will to take revenge for herself as well as for other helpless women, 'You are a lie.' he says. 'No. I am not telling you a lie. You have another wife and I have another husband. We are even' (Farah 145). If the society treats girls like "materials, just like objects, or items on the shelf of a shop", who can be "sold and bought as shepherds sold their goats at market-places" (Farah 84), then Ebla decides to be her own shopkeeper and determine her own price. Accordingly, she has her revenge upon Awill by "marrying" Tiffo secretly, and upon Tiffo by telling him that she has "another husband". The way Ebla speaks to Tiffo here shows how self-confident and aggressive she becomes. She also challenges his pride as a man who does not expect such an attitude from a woman. Furthermore, she makes Tiffo taste the same sense of sullenness that a woman experiences from her husband's polygamous marriages. Although her deed goes in opposition to Quranic teachings, and her so called "second marriage" is perceived as adultery by Islamic jurisdiction, Farah's representation of Ebla's reaction is meant to delineate an exaggerated form of feminist resistance that may counterbalance female oppression in the name of religion.

Ebla is introduced to the reader as an opposing figure to the ideal, religious Muslim woman. Ebla is rather presented as a rebellious woman who has her own code of right and wrong, "She thought about things and people in her own way. ... She thought of many things a woman of her background would never think of" (Farah 8). Ebla knows that God created woman from a man's crooked rib, but as she tries to unbend her own life, she comes full circle to the belief that it is not women alone who 
are bent, but also the world around them. While she attempts to straighten out the crooked rib of her life, she warns her husband that "if anyone [else] tries to straighten it, he will have to break it" (Farah 179). At the end of the novel, Ebla wonders if she has to disclose her infidelity to Awill or to keep it as a secret:

"Tomorrow," said Awill, moving towards her with desire. "Tomorrow. We will tell each other everything tomorrow. You'll tell me everything, and I shall tell you everything." Ebla smelt his maleness. She touched his forehead and, as usual, he was hot with desire. He smiled at her and she smiled back at him. "Poor fellow, he needs me," she thought. "He is sex starved" (Farah 179).

Ebla's self-fulfillment is completed in the closing lines of the novel once her husband, Awill, has returned home, "I am master of myself" (Farah 178), as she is no longer submissive and obedient. She does not want the role of a daughter, a wife or a mother predetermined by traditional clan relations. She wants to be herself. Although she is seen as a sinful woman, Ebla is confident that "with tomorrow's sun maybe happiness will come to me" (Farah 159).

Similarly, the politics of resistance are incarnated in The Secret Lives of Baba Segi's Wives through women's utilization of their bodies, through women's solidarity, through economic independence, and through education. When Ebla underscores her power over her husband due to his weakness against his sexual impulses, Iya Segi expresses the same point about her husband, "women are my husband's weakness. He cannot resist them" (Shoneyin 103). Ironically enough, though equipped with powerful control over women, Baba Segi is depicted in Shoneyin's novel as impotent. Since society constructs man as a powerful perfect being, he is expected to be fertile; infertility is, therefore, a stigma describing women's imperfection. According to Odinga, the society constructs "masculinity, manhood and fertility through the ability of the man to have children [and] since male[s] are inherently fertile, infertility and childlessness were [historically] considered feminine" (463). Shoneyin's The Secret Lives of Baba Segi's Wives, accordingly, subverts this socially accepted norm by presenting an impotent male character. The narrative speaks what Odinga calls "the unspeakable" (465) and challenges the patriarchal system by attributing infertility to male characters. Shoneyin presents the polygamous Baba Segi as impotent who possesses neither the skill of pleasing his wives' sexual desires nor the capability of impregnating them. 
While Ebla along with other women make an all-female community within the patriarchal hemisphere to sustain each other in their negotiations with their menfolk, three wives in Baba Segi's household, in the same African feminist fashion, start their negotiation journey as a united group. The female characters in Shoneyin's novel exploit polygamy as a social institution to challenge and disrupt patriarchal power. Women in polygamous institutions, accordingly, subvert the notion that a woman's body is her weakness. Instead, those women use body as a means of negotiating their rights with other men who are stigmatized with impotence and irresponsibility.

When they meet in Baba Segi's compound with their shared traumas, Iya Segi, Iya Tope and Iya Femi construct their own community to take revenge from the patriarchal system by subverting its gender power relations. In this respect, the narrator says, "the only chance we had was to be united" (Shoneyin 70). Their union is, therefore, seen as a power-bloc within the family that will eventually coerce abusive husbands to behave well with their life mates. Silberschmidt observes that such community reveals these women as having potent identity "conforming to the patriarchal norm overtly [while] secretly subvert[ing] it" (245). This means that on the surface women are seen as victims, while implicitly they are agents in their families. This argument is supported by Iya Segi's powerful speech about her agency:

My husband only thinks he controls this household and I let him believe that he does. I want him to believe he does but I am the one who keeps this household together. Good things happen here because I allow them. I alone can approve vengeance and only I know how to bring calm (Shoneyin 104).

Shoneyin presents radical women who step out of their prescribed roles: virtuous and submissive housewives. When Iya Segi realizes that Baba Segi cannot produce children, she secretly dates Taju, Baba Segi's driver, who effectively impregnates her. Iya Segi, later on, shares this secret of looking for men out of wedlock with her co-wives, Iya Tope and Iya Femi. Moreover, she decides to exploit her sexuality to reclaim her money from Iya Segi by asking him to allow her to open some shops for herself. Although Iya Segi does not enjoy sexual intercourse with Baba Segi, she keeps pleasing his ego, "I will follow you anywhere, my lord" (Shoneyin 103). 
Iya Tope follows Iya Segi's footsteps by using her body as a means of resistance and negotiation. Interestingly enough, it is Iya Tope who initiates the affair with the meat-seller, using her body to signal her desire. She, therefore, disrupts the patriarchal convention that affirms man's sexual initiation and women's passivity of sexual attention. Strikingly, however, it is Iya Tope who pays for her sexual pleasure, a fact which turns the sexual relationship between men and women upside down. It is no longer that the female body is seen as a commodity who is sold and bought by men; in this case it is the male body which is bought by women. Iya Tope manages to maintain her affair with the meat-seller for four years, an affair which produces three girls, illegally attributed to Baba Segi.

Empowered by her body and her beauty, Iya Femi listens to Iya Segi's advice by getting pregnant out of wedlock to keep her position in her husband's household. She, therefore, exploits her sexuality for the same reasons: reproduction and sexual pleasure. Iya Femi maintains her past relationship with Tunde, the son of a woman to whom she was working, who also fathers her two children. She also uses her sexuality to seduce Baba Segi through female tactics. Showing apparent obedience, she intends to make Baba Segi favor her more than the other wives. Iya Femi deliberately uses her sexuality to challenge the very patriarchal power which aims to make her gender and sexuality subsidiary to men.

One of the important politics of feminist resistance suggested in the narrative is education. While Iya Segi, Iya Tope and Iya Femi turn the threat of Baba Segi's infertility to their own cultural advantage as wives, and in some cases to seek the fulfillment of their sexual impulses, Bolanle is introduced as a foil to those sinful wives in Baba Segi's household. She is the representative of the promising Nigerian woman whose reliance on education and scientific thinking diminishes the power of her male counterparts. She is determined to educate her co-wives to understand their roles, not only as wives, but as human beings. She is willing to teach them how to read, but their response is always unenthusiastic. This symbolically underscores the difficult mission of the African feminist writers of deconstructing oppressive gender practices deeply seated in their societies

The coming of Bolanle, a university graduate, exposes the impotence of Baba Segi. Baba Segi is perfectly willing to have a medical test since he believes that he has already fathered seven children. But then- to his own and everyone's dismay, he discovers the shocking fact that the problem lies with him; he is impotent, "there's nothing! Not a 
solitary sperm swimming around!" (Shoneyin 219) Accordingly, the narrative interrogates assumptions about fatherhood and polygamy in modern day Nigeria.

Being equipped with education, Bolanle is eventually able to fight back her patriarchal oppressor. By doing so, Bolanle has, as Odinga argues, "challenged [the] traditional authority, which institutionalized the constructions of female identity based on their reproductive function and sexuality, especially a woman's ability to procreate" (465). Through Bolanle's power, Baba Segi's ego as a fertile husband is shaken. Holding a meeting with his wives to see the decision to be taken after realizing that he is impotent and thus none of the children in his household is his, their dialogue acts as a space in which this family negotiates gender roles by bringing together males and females as equal members. It is Bolanle who asks for divorce whereas the rest of Baba Segi's wives beg him for keeping them as wives. It is at this point in the story that we feel the triumph of Bolanle's emancipation process. In a way she acts as a disruptive tool in Shoneyin's hand, a tool with which she discloses the nasty male-centered structure of the polygamous marriage. For Bolanle, living under the humiliating conditions of the broken Baba Segi is to lose one's dignity. She divorces him because she believes life can give her other alternatives. She, accordingly, neglects her social stigma as a 'divorced' woman who is not sustained with a male protector.

Bolanle's effect as a deconstructive tool in the narrative can be traced through the examination of Baba Segi's two contradictory pieces of advice given to his elder son, Kole. At the outset of the novel, and empowered with his (false) virility, Baba Segi asks his son to "grow big and strong so [Kole] can marry many wives and bear many children' (Shoneyin 10). However, due to Bolanle's power that makes him recognize the bitter truth of his infertility, Baba Segi seems that he learns the lesson:

When the time comes for you (Kole) to marry, take one wife and one wife alone. And when she causes you pain, as all women do, remember it is better that your pain comes from one source alone. Listen to your wife's words, listen to the words she doesn't speak, so that you will be prepared. A man must always be prepared (Shoneyin 238).

In The Secret Lives of Papa Segi's Wives, Shoneyin condemns the polygamous family structure, suggesting a new form of familial structure that can disrupt the patriarchal hegemony and empower women by 
depicting impotent and irresponsible men. In terms of death and rebirth, Shoneyin is keen to witness the annihilation of patriarchal pillars in her society allowing for a more egalitarian hemisphere where women are eventually seen as equal partners to men.

The selected novels reflect the mechanisms through which African Feminism operates within two African countries: Somalia and Nigeria. Nuruddin Farah and Lola Shoneyin, with their diverse cultural, ideological, philosophical, religious backgrounds are put together to examine their stances and visions towards interrelated issues of sexuality, polygamy, gender, sexual abuse, and feminist resistance. The two narratives, regardless of their diversity in setting and residence of authors, speak to each other and engage readers to re-read the predicament of the African woman in these societies.

Although the two narratives have much in common, From a Crooked Rib is seen as the novel which fosters the idea of individual development towards independence, freedom, and awakening. None of the female characters in Lola Shoneyin's novel shows this attribute. Through Ebla, Farah demonstrates a woman's individuality and determination to fight her male oppressors and to achieve emancipation. Unlike other women characters in Shoneyin's novel who surrender to forced marriages, Ebla escaped twice from this marriage considering it indecent for women. Though illiterate, Ebla proves the falsity of the patriarchal notion that women lack the quality of being rational. Ebla, a prototype of African Feminism, invalidates the western feminist assumption that third world women are immature and unable to speak for themselves.

While Ebla along with other female characters in the two narratives use their bodies as a domain of resistance but within the confines of the patriarchal system represented by the family, Bolanle, in The Secret Lives of Baba Segi's Wives, relies on education to fight back her oppressor. Through Bolanle, Shoneyin stresses the point that most African women resist: 'yes, you can do it and lead a life without a man'.

God has created men and women to be different. Instead of being hailed and thus complementary, these differences have, in many societies, brought about an unbalanced relationship between men and women. In sexist societies, women are incarcerated by the socially-created beliefs about their irrationality and imperfection in sharp contrast to men. Stressing female submission along with male wickedness in implementing boundaries of sexual behavior, Nuruddin Farah and Lola Shoneyin clearly attack the unrestrained male hypocrisy and social 
prejudice which are at the root of the patriarchal structure of their societies. By highlighting the politics of resistance their women characters have adopted, these writers are subverting the dogmatic sexist beliefs that create the superior-inferior relationship between men and women.

Although Farah and Shoneyin do not condemn religion to be the root cause of women's suffering, they embrace the values of liberal humanism, replacing the pious Muslim believer with the doubting Enlightenment individual. Rather than seeking answers in the Qur'an, as a pious Muslim would, their characters search for them in themselves. Accordingly, Farah and Shoneyin emphasize individual responsibility which entails constructing one's personal code of right and wrong.

By raising the issues of gender discrimination, From a Crooked Rib and The Secret Lives of Baba Segi's Wives proclaim the possibility of constructing new social spaces and identities. The narrative spaces create opportunities for female social participation and individual expression, while maintaining the feminist African principle that man is not an "enemy" and that women's roles as wives and mothers are highly appreciated. Women are presented in the two narratives as independent individuals who adeptly negotiate their rights. As Coughlin points out that women are the best negotiators because they are oriented to "social relationships through which [they] are connected to others" and "they are better listeners" (324).

As stated earlier, contemporary African feminist writers are no longer preoccupied with the body of the African woman as an allegorical entity representing national issues. Rather, these writers are interested in the female body as a violated space. When they present stories, usually based on true stories, about female circumcision, polygamy, barrenness, spousal abuse, and rape of women, they do so to speak the "unspeakable". They are not shy to talk about taboos; they debunk explicit sexual discourses that ultimately oppress and degrade women's lives. In this regard, Kaigai contends that it is through bodies "narratives invite the reader to reflect on how certain forms of power and domination are gendered in particular ways and how stories present the gendered body as an unstable field of power contestation" (12). This is the leading idea that runs through the two narratives.

The narratives also suggested that in any society where women are not free to control their bodies or to follow their dreams freely as men do, women cannot be expected to be virtuous. On the surface, women can comply with social religious norms; secretly, however, they may violate 
such norms. When the women of the two narratives exhibit readiness to and acceptance of sinful behavior out of wedlock, they do so secretly. Female virtue cannot be controlled. Rather, it is a matter of personal code of right and wrong. In order for virtue to reign in a society, Farah and Shoneyin suggest, freedom and equality should be available for both men and women. In the absence of these two essential ideals, the female body will be representing an endless conflict between docility and resistance. 


\section{Works Cited}

Adeleye-Fayemi, Bisi. "Creating and Sustaining Feminist Space in Africa:

Local-global Challenges in the $21^{\text {st }}$ Century." Ontario Institute for Studies in Education of the University of Toronto, Centre for Women's Studies in Education, 2000.

al-Hilali , Muhammad T. and Muhsin Khan, Muhammad. (1993). Translation of the Meanings of the Noble Quran: KSA (Madina): King Fahd Complex for the Printing of the Holy Qur'an.

Alison, M. Jaggar, and Young, Iris, Marion. Eds. A Companion to Feminist Philosophy. Malden Mass: Blackwell, 1998.

Amos, Valerie and Parmar, Parmar. "Challenging Imperial Feminism." Feminist Review, vol. 17, 1984, pp. 3-19.

Arndt, Susan. The Dynamics of African Feminism: Defining and Classifying African-Feminist Literatures. Africa World Press, 2002.

Chinweizu, Ibekwe. Anatomy of Female Power: A Masculinist Dissection of Matriarchy. Lagos: Pero Press, 1990.

Coughlin, Richard W. "Gender and Negotiation in Model UN Role-Playing Simulations". Journal of Political Science Education. Vol.9:3. 2013, pp. 320-335.

Dolphyne, Florence A. The Emancipation of Women: An African Perspective. Accra: Ghana Universities Press, 1991.

Eze, Chielozona. Ethics and Human Rights in Anglophone African Women's Literature. Palgrave Macmillan, 2016.

Farah, Nuruddin. From A Crooked Rib. London: Heinemann, 1970.

Fredua-Agyeman, Nana. "Conversation with Lola Shoneyin, author of the Secret Lives of Baba Segi's Wives."

ImageNations http://freduagyeman.blogspot.co.za/2011/01/conversation-withlola-shoneyin-author.html. 7 January 2011. Accessed 15 January 2017. 
Hogan, Patrick Colm. Colonialism and Cultural Identity: Crises of Tradition in the Anglophone Literature of India, Africa, and the Caribbean. NY: State University of New York Press, 2000.

Kaigai, Ezekiel K. Encountering Strange Lands: Migrant Texture in Abdulrazak Gurnah's Fiction. Unpublished $\mathrm{PhD}$ thesis, Stellenbosch University, 2014.

Mbiti, John. Introduction to African Religion. London: Heinemann, 1975.

McLeod, John. Beginning Postcolonialism. Manchester: Manchester University Press, 2000.

Mikell, Gwendolyn. African Feminism: The Politics of Survival in Sub-Saharan Africa. Philadelphia: University of Pennsylvania Press, 1997.

Ndabayakhe, vuyiswa. and Addison Catherine. "Polygamy in African fiction." Current Writing: Text and Reception in Southern Africa. Vol. 20:1, 2008, pp. 89-104.

Ngcobo, Lauretta. "African Motherism: Myth and Reality". Criticism and Ideology. Second African Writers' Conference Stockholm, 1986, pp. 138147

Nnaemeka, Obioma. "Urban Spaces, Women's Places: Polygamy as Sign in Mariama Bâ's Novels." The Politics of (M)Othering: Womanhood, Identity, and Resistance in African Literature. Ed. Obioma Nnaemeka. London: Routledge, 1997, pp.162-191.

Odinga, Agnes. 'I am not Tassa, He is not a Man Like Other Men': Feminising Infertility and Masculinising Fertility in South Nyanza, 1945-1960". Ed. Tamale, Sylvia. African Sexualities: A Reader. Cape Town: Pambazuka, 2011, pp.463-469.

Ogundipe-Leslie, Molara. "African Women, Culture and Another Development." Re-Creating Ourselves: African Women and Critical Transformations. Asmara: Africa World Press, 1994: 21 - 41

Ojo-Ade, Femi. "Female Writers, Male Critics". African Literature Today 13. London: Heinemann, 1983.

Okin, Susan Moller. Is Multiculturalism Bad for Women? New Jersey: Princeton University Press, 1999. 
Okonkwo, Juliet I. "Farah and the Individual's Quest for Self-Fulfillment". Okike 29, 1989, pp. 66-74.

Oriel, Jennifer. "Sexual Pleasure as a Human Right: Harmful or Helpful to Women in the Context of HIV/AIDS?" Women's Studies International Forum 28, 2005 pp. 392- 404.

Ouzgane, Lahoucine \& Morrell, Robert (Eds.) African masculinities: men in Africa from the late nineteenth century to the present. New York: Palgrave Macmillan, 2005.

Oyewumi, Oyeronke. Ed. African Gender Studies: A Reader. Palgrave Macmillan US, 2005.

Pfaff, Françoise. "Three faces of Africa: Women in Xala." Jump Cut: A Review of Contemporary Media, Vol. No. 27, July 1982, pp. 27-31.

Pucherova, Dobrota. "Islam, Tradition and Modernity in the Work of Two Somali Writers: Nuruddin Farah and Ayaan Hirsi Ali." English Studies in Africa, 59: 2, 2016, pp. 27-40.

Sawicki, Jana. Disciplining Foucault: Feminism, Power, and the Body. New York: Routledge, 1991.

Shoneyin, Lola. The Secret Lives of Baba Segi's Wives. London: Serpent's Tail, 2010.

Silberschmidt, Margrethe. "Have Men Become the Weaker Sex? Changing Life Situations in Kisii District, Kenya" Journal of Modern African Studies. 30: 2, 1992, pp. 237-253.

Steady, Filomina Chioma. "African Feminism: A Worldwide Perspective." Women in Africa and the African Diaspora. Eds. Rosalyn Terborg-Penn, Sharon Harley, and Andrea Benton Rushing. Washington, D.C: Howard University Press, 1987, pp. 3-24

Sudarkasa, Niara. 'The Status of Women in Indigenous African Societies'. Feminist Studies Vol. 12, No. 1 (Spring, 1986), pp. 91-103

Tyson, Lois. Critical Theory Today. Rutledge: Princeton University Press, 2006. 